\title{
Lietuvos šaulių sąjunga valstybės gynyboje XX a. 4-ajame dešimtmetyje: šaulių parengtis karinėms užduotims vykdyti
}

\author{
JONAS VAIČENONIS \\ Klaipedos universiteto Baltijos regiono istorijos ir archeologijos institutas \\ Herkaus Manto g. 84, LT-92294 Klaipeda \\ El.paštas j.vaicenonis@hmf.vdu.lt
}

\begin{abstract}
Per pirmaji XXI a. dešimtmetị lietuvių istoriografijoje yra ịrodyta, kad pokario antisovietinès rezistencijos metu ženklų vaidmenį atliko šauliai. Natūralu, kad didžioji dalis jų karinių ir organizacinių gebėjimų formavosi Lietuvos šaulių sajungos veiklos metais taikos metu, t. y. XX a. 4-ajame dešimtmetyje, kai vyko intensyvus kariuomenès modernizavimo ir reformavimo bei Lietuvos šaulių sajungos integracijos i valstybès gynybos sistemą procesas. Šio straipsnio (1) tikslas - išanalizuoti šaulių parengties karinėms užduotims vykdyti raidą, keliant hipotezę, kad ịvairiuose mokymuose igyta kovinè patirtis ne tik galejo, bet ir turèjo būti panaudota $1944 \mathrm{~m}$. prasidejusio partizaninio karo Lietuvoje metu.
\end{abstract}

Raktažodžiai: Lietuvos šaulių sąjunga, partizaninio karo taktika, Lietuvos kariuomené, valstybès gynyba, partizaninis karas

\section{IVADAS}

Analizuojant pokario rezistenciją, „Karą po karo“, galima konstatuoti buvus tiesioginị ryši tarp Pirmojoje Lietuvos Respublikoje veikusios paramilitarinès organizacijos - Lietuvos šaulių sąungos, kuri iš esmès dvidešimt metų buvo rengiama partizaninio karo veiksmams, ir 1944-1953 m. vykusių partizaninio karo veiksmų. Nuolat augančią šaulių parengti partizaniniam karui tarpukario Lietuvoje pastaraisiais metais savo moksliniuose tyrimuose yra atskleidęs Vytautas Jokubauskas [31; 32]. Nuoseklų šaulių kovos kelią sovietų ir vokiečių okupacijos metais, o sykiu ịsiliejimą ị partizaninès kovos sūkurị kiek anksčiau yra analizavę istorikai Dalia Kuodytė [34], Dainius Noreika [39] ir Sigitas Jegelevičius [28; 30].

(1) Straipsnis parengtas igyvendinant Lietuvos mokslo tarybos finansuojamą mokslininkų grupių projektą „Paramilitarinių organizacijų reikšmè valstybès gynybos sistemoje: Lietuvos šaulių sąungos atvejis" (MIP-001/2013). 
Atlikti moksliniai darbai, o kartu siekis įvertinti 1944-1953 m. Lietuvos partizaninị karą tam tikru kokybiniu požiūriu leidžia tyrèjams kelti naujus inovacinius mokslinių tyrimų uždavinius. Apžvelgiant Lietuvos partizaninio karo eigą ir matant gana ženklų buvusių Lietuvos šaulių sąjungos narių dalyvavimą vadovaujančioje grandyje, kyla idejja aptarti ir išanalizuoti būsimų kovotojų patirtis ir karinius gebejjimus. (Iš aštuonių $1949 \mathrm{~m}$. vasario $16 \mathrm{~d}$. LLKS Tarybos Prezidiumo Deklaracijos signatarų du buvo šauliai. Tarp 50 partizanų apygardų, sričių vadų bei LLKS Tarybos narių 7 buvo šauliai [52]. Partizanų apygardų štabų nariais, kartu būrių ar kuopų vadais buvo dar daugiau šaulių [23; 35; 36; 42; 48; 49; 50; 51], tačiau iki šiol nèra jų statistikos duomenų.) Ši patirtis neatsiranda čia ir dabar, ji formuojasi per kur kas ilgesnị laiką mokymų ir pratybų procese, palaipsniui igyjant vis naujų gebejjimų, kuriuos, reikalui esant, galima būtų pritaikyti praktikoje. Todèl mūsų tyrimas krypsta į XX a. 4-ąjį dešimtmetį, kai šauliai, tapę Lietuvos Respublikos gynybos sistemos sudedamąja dalimi, intensyviai buvo rengiami jiems planuose patikètoms kovinèms užduotims, o ši patirtis, galima teigti, labai pravertè prasidejjus nuožmioms partizaninèms kovoms su Sovietų Sąjungos represinèmis struktūromis.

Norint igyvendinti užsibrèžtą tikslą, svarbu atsakyti ị keletą klausimų. Jeigu remsimès faktu, kad dalis pokario partizanų struktūrinių padalinių formavosi buvusių šaulių padalinių - būrių ar kuopų pagrindu, tada, manome, būtų tikslinga išanalizuoti šių padalinių sudètị ir taktinius gebejimus kiek detaliau, o hipotetinius teiginius pailiustruoti atskiromis ir bendras tendencijas atspindinčiomis įžvalgomis. Taip pat yra svarbu patyrinèti pati mokymo ir karinio rengimo procesą - pažvelgti ị jo organizacinius principus, aptarti, ko buvo mokomi šauliai. Visa tai leistų pagrịsti teiginį, kad per kelerius rengimo metus sukaupta patirtis buvo realizuota (ar iš dalies) partizaninių kovų už valstybès laisvę metu. Mūsų tyrimo objektas -Lietuvos šaulių sąjungos padalinių ir atskirų asmenų parengtis valstybės gynybos užduotims vykdyti. Paskutiniais dešimtmečiais Lietuvos istoriografijoje pasirodė naujų Lietuvos šaulių sąungos istorijos tyrimų, kuriuose atskleidžiami organizacijos rengimo partizaniniam karui principai [31;32], veikla Lietuvos valstybès kūrimosi aušroje [46; 33; 27], šios paramilitarinès organizacijos ideologiniai aspektai [45; 47;38], studentų dalyvavimas šaulių veikloje [26], paramilitarinių junginių integracijos ị valstybės gynybos sistemą bruožai [43; 44], atskirų LŠS rinktinių ar smulkesnių padalinių istorijos bruožai [37; 29] ir kt. Nepaisant tokio plataus tyrimų spektro, vis dar trūksta gilesnès analizès, kuri atskleistų šaulių îgytą karinių užduočių patirtị rengiantis ginti valstybę ir valstybingumą. Atlikus platesnị tyrimą ateityje būtų galima įvertinti ir iš esmès peržiūrèti LŠS narių indèlį Lietuvos partizaniniame kare 1944-1953 metais. Siekdami užsibrèžto tikslo pradžioje apžvelgsime Lietuvos šaulių sąjungos padètį valstybès gynybos sistemoje XX a. 4-ajame dešimtmetyje ir jai keliamus uždavinius bei paanalizuosime šaulių parengtị minėtiems uždaviniams ịgyvendinti.

\section{LIETUVOS ŠAULIAI - VALSTYBĖS GYNYBOS SISTEMOS DALIS}

$\mathrm{XX}$ a. 4-ojo dešimtmečio antrojoje puseje, artëjant naujo karo grèsmei, dauguma Europos valstybių susirūpino savo saugumo užtikrinimo perspektyvomis. Ši problema ypač buvo aktuali mažoms valstybėms, kurių gynybą galèjo užtikrinti tik visuotinių jègų mobilizavimas ir totalus tautos pasipriešinimas. Kaip ir kitur Europoje, taip ir Lietuvoje vyko panašūs procesai. XX a. 4-uoju dešimtmečiu Lietuvoje reformuojant kariuomenę žvilgsnis buvo sutelktas ị keletą paramilitarinių organizacijų, kurios sudarè visuomeninį valstybès gynybos stuburą. Tai buvo Lietuvos skautų sąjunga, Lietuvių tautinio jaunimo sąjunga „Jaunoji Lietuva“ ir gausiausia paramilitarinė organizacija - Lietuvos šaulių sąjunga. Būtent šiuo periodu LŠS tapo viena 
pagrindinių visuomenę konsoliduojančių jègų [43, 110]. 1940 m. jos gretose jau buvo daugiau nei 80 tūkst. Lietuvos žmonių [32, 388].

XX a. 4-ojo dešimtmečio antrojoje pusẻje Šaulių sąungos organizacinèje struktūroje veikè 22 rinktinès, iš jų 21 atitiko valstybès administracinį suskirstymą, o XXII, vadinamoji „Geležinkelių“, buvo suformuota dèl geležinkelių apsaugos. 1939 m. praradus Klaipėdos kraštą ir atgavus Vilnių, atitinkamai buvo likviduota XX Klaipėdos rinktinè ir suformuota XXIII Vilniaus rinktinè. Rinktines sudare būriai ir kuopos, kiekvienas būrys buvo formuojamas iš 3-5 šaulių skyrių [41, 770-771]. Rintinèse buvo daugiau nei 850 vyrų ir daugiau nei 50 moterų šaulių būrių $[32,388]$, plačiai pasklidusių po visą Lietuvos teritoriją.

Analizuodami aptariamojo laikotarpio šaulių padalinių sudètį, kaip pavyzdị pasitelksime archyvinę informaciją apie XX a. 4-ojo dešimtmečio antrosios pusès Ukmergès krašto šaulius. Ukmergès rinktinei priklausė 35 vyrų ir 4 atskiri moterų būriai su 643 nemobilizuojamojo amžiaus šauliais. Būrių vadų pareigas èjo 15 atsargos karininkų, 7 puskarininkiai, 1 eilinis, 12 netarnavusiųjų kariuomenèje ir 4 šaulès moterys. 83 \% netarnavusių kariuomenèje būrių vadų buvo mokytojai. Taip pat užfiksuota, kad rinktinejje buvo 28 atsargos karininkai šauliai; 56 \% visų šaulių būrių sudèties buvo tarnavę kariuomenëje. Ginkluotę sudarẻ 502 šautuvai ir 364 pistoletai [1, 1-17]. Panaši buvo ir kitų šaulių padalinių sudèties struktūra, išskyrus Kauno ir „Geležinkelių“ rinktines. Atkreiptinas faktas, kad iš paminètų Ukmergès rinktinès būrių 27 būrių būstinè buvo mokykla, kurioje vyko pati ịvairiausia veikla. Reikia pažymèti, kad didelè dalis mokyklose dirbusių mokytojų, kartu ir mokyklų vedejjų, aptariamu laikotarpiu buvo šauliais ir intensyviai dalyvavo karinio rengimo procese. Tarp rengiamų šaulių buvo ir nemažai ūkininkų bei valstybès tarnautojų $[12,67 ; 13,64 ; 22,152]$.

Modeliuojant valstybės gynybinius planus karo atveju, kariuomenės vadas brg. gen. Stasys Raštikis numatė šaulius panaudoti aktyviai sienos apsaugai $[43,113]$. Bendraja prasme šauliams buvo priskirta partizaninio veikimo taktika, plačiai išnaudojant miškus, pelkes ir t. t., paskirtame plote ar tam tikra kryptimi kiek galima daugiau įrengti kliūčių ir jas ginti, o atsidūrus priešo užnugaryje staigiais ir netikètais puldinejjimais ji terorizuoti. Šauliai privalèjo greitai susirinkti ir būti pasirengę igyvendinti numatytus uždavinius. Jie turèjo pradèti veikti gavę ịsakymą arba, priešui staiga puolant, paskirtus uždavinius ịgyvendinti nelaukiant aukštesnès vadovybès nurodymo ir veikti savarankiškai. Toks taktinis veikimo principas, suteikiant asmeninès iniciatyvos laisvę, tuo metu buvo žinomas ir taikomas Europos karyboje, ypač Vokietijoje $[24,51]$. Lenkijos ir Vokietijos pasienyje esančios šaulių rinktinès buvo pavaldžios arčiausiai sienos esančių dalinių vadams. Joms buvo iškelti šie uždaviniai: a) karo pavojaus atveju uždaryti ir saugoti sieną; b) priešui veržiantis per sieną, jam trukdyti ir ženklinti jo pasiektas ribas, rinkti apie priešą žinias; c) vèliau kartu su priedangos daliniais varžyti priešo slinkimą i šalies gilumą. Šiems tikslams atlikti numatyta pasitelkti ar ịpareigoti šaulius, kurie per kariuomenės mobilizaciją yra nešaukiami, be to, jie turèjo būti „lietuviško nusistatymo ir pilnai patikimi“ $[43,113]$. Šaulių sąungos vadovybè privalëjo rūpintis tik sienos apsaugai priskirtų rinktinių komplektavimu ir organizacija, apie darbų vykdymą informuoti atitinkamą divizijos vadą. Šaulių būrių pagrindu buvo sudarytas ir dvylikos pasienio apsaugos batalionų tinklas, kurio dèka, be kitų šaulių padalinių, buvo uždengta pietvakarių-pietų-pietryčių Lietuvos valstybinè siena. Kai kurie pasienio apsaugos batalionai buvo sudaromi pasitelkiant ir pasienio policijos pajègas. Visi batalionai buvo pavaldūs pėstininkų divizijų vadovybei: I-III PAB - III PD; IV-IX PAB - II PD; X-XII PAB - I PD [43, 113-114]. Vykdant mobilizaciją dauguma šaulių turẻjo būti pašaukta ị reguliariąją kariuomenę. Visi kiti šauliai pagal divizijų vadų nurodymus ir komendantų ịsakymus buvo numatyti sargybos tarnybai 
pasienyje. Pagrindinis numatytų uždavinių krūvis teko II pėstininkų divizijai, nes jai pavaldūs šaulių ir pasienio apsaugos batalionai dengè pietinį-pietvakarinị valstybès sienos ruožą - pagrindinę tuo metu numanomo priešininko puolimo kryptị. $1938 \mathrm{~m}$. vadovaudamasi Kariuomenès štabo nurodymais „Šauliams mobilizacijos ir operacijų metu panaudoti“ [2, 4-7] divizijos vadovybè išdèstè savąji šaulių panaudojimo planą [6, 35-38]. Siekiant užtikrinti atskirų krypčių šaulių būrių pajègumą, numatyta atitinkamų būrių šauliams mobilizacinius paskyrimus nukreipti ị tuos pačius būrius. Taigi ị gynybinių uždavinių ịgyvendinimą kariuomenès vadovybe žiūrẻjo gana lanksčiai. Operatyviniai uždaviniai šaulių būriams turẻjo būti parengti taikos metu, iš anksto numatant kieno pavaldumui padaliniai priklauso, ką ir kaip turi atlikti. Pradiniu kovų laikotarpiu šaulių padaliniai turejjo veikti savarankiškai. Greta operatyvinių priešo stabdymo ir Lietuvos kariuomenès mobilizacijos priedangos uždavinių šauliams buvo numatyti ir kai kurie apsaugos uždaviniai, pavyzdžiui, tiltų apsauga: pradžioje tiltas saugomas, o priešui prisiartinus ginamas ir naikinamas. Svarbu pažymèti ir tai, kad šaulių būriams skiriamos užduotys ir pirmųjų kovų su priešininku akistata buvo numatomos šalia jų gyvenamosios vietos. Taip ne tik siekta didesnès motyvacijos kovai, būta ir praktinès priežasties - kad šaulys kovotų jam gerai pažistamoje teritorijoje. Šaulių mokymas turèjo būti nukreiptas ir i partizaninius veiksmus. Mokymu turejo rūpintis divizijos vadas ir priedangos dalinių vadovybė. II PD atveju - 9-ojo péstininkų ir 2-ojo ulonų pulkų vadai. Iki 1939 m. sausio 1 d. šaulių būriams turèjo būti suformuluoti uždaviniai, o iki balandžio $1 \mathrm{~d}$. ir konkretūs jų panaudojimo planai.

1939-1940 m. dar kelis kartus buvo skelbiami nauji ịsakymai, kuriuose užduotys šaulių padaliniams ir pasienio apsaugos batalionams buvo koreguojamos ir nuolat papildomos. 1940 m. pradžioje Lietuvos karinès vadovybès dèmesys nukrypo ị Vokietijos pusę. Būtent iš čia, jos manymu, kilo didžiausia grèsmè ir tikètasi Lietuvos užpuolimo. $1940 \mathrm{~m}$. balandžio mènesį, siekiant užtikrinti pagrindinių kariuomenès pajègų pasirengimą galimai mobilizacijai, kariuomenès vadas ịsakè mobilizacijos priedangai panaudoti visus šaulius. Pagrindinis šaulių uždavinys buvo rengti ịvairias kliūtis, trukdančias priešo motorizuotų, mechanizuotų dalių judejjimą (ardyti, deginti ir sprogdinti tiltus, kelius užversti medžiais ir akmenimis, užbarikaduoti kelius, gatves ir kitus siaurus praejjimus ir t. t.). Didesnes ir sunkiau apeinamas kliūtis buvo nurodoma ginti. Svarbiausia buvo stabdyti priešo judrių dalių judejjimą. Šalutiniai šaulių uždaviniai buvo svarbesnių objektų - tiltų, svarbesnių pastatų, telefono stočių ir kt. - saugojimas priedangos zonos gilumoje. Likusieji priešo užnugaryje turëjo vykdyti partizaninius veiksmus (naikinti atskirus priešo karius ir smulkesnius dalinius, gadinti bei naikinti priešo naudojamus įrenginius - telefono linijas, geležinkelius, tiltus ir kt.), taip pat atlikti kariuomenės žvalgybos funkcijas - rinkti žinias apie priešą ir jas perduoti artimiausiems savos kariuomenès daliniams. Minėtuose nurodymuose buvo pabrěžiama, kad šaulys, dèl ịvairių aplinkybių priverstas pasilikti priešo užnugaryje, be atskiro ịsakymo, savo iniciatyva pagal aplinkybes pradeda vykdyti partizaninius uždavinius. Ši jo veikla ịvardyta kaip labai garbinga, bet kartu sunki ir pavojinga, todèl veikdamas jis turi imtis visų atsargumo priemonių ne tik priešo, bet ir vietinių mums, lietuviams, nepalankiai nusistačiusių gyventojų atžvilgiu.

$1940 \mathrm{~m}$. balandị buvo apibrèžti nauji uždaviniai pasienio apsaugos batalionams:

A. Iki priešui įsiveržiant ị mūsų teritoriją, kai priešas dar nepuola: a) uždaryti sieną PABn skirtame bare: nutraukti judejimą per sieną, kovoti su kontrabanda, kovoti su nelegaliu sienos perejimu tiek iš vienos, tiek iš kitos pusès; b) $2 \mathrm{~km}$ platumo pasienio ruože įrengti kliūtis bei ịvykdyti ardymo darbus, kad būtų sutrukdytas priešo motorizuotų dalių judèjimas; c) Kariuomenès štabo II skyriaus instrukcijos nurodymais rinkti žinias apie pasienyje 
telkiamą svetimą kariuomenę bei gyventojų nuotaikas anoje puseje, tam tikslui pasinaudojant taikos metu pasienio policijos turimu agentų tinklu.

B. Priešui veržiantis ị mūsų teritoriją: a) smulkių priešo žvalgomųjų dalinių, ịsibrovusių i mūsų teritoriją, sunaikinimas, paèmimas nelaisvèn arba nubloškimas atgal per sieną; b) priešo stambesnių jẻgų puolimą stabdyti pasipriešinant už iš anksto ịrengtų ir vietos šaulių bei kariuomenès dalinių ginamų kliūčių; c) sustabdžius priešą, kartu su šauliais ginti patikètą barą $[19,7-8]$.

Igyvendinant kariuomenès vado nurodymus, šaulių rinktinių vadai, tarpininkaujant II pėstininkų divizijos štabui, atsakingam už valstybės pietų ir pietvakarių krypties gynybą, privalèjo organizuoti patalpas šaulių ginkluotei. Neturint pakankamai tokių patalpų, i̇ pagalbą atėjo ne tik Vidaus reikalų, bet ir Žemès ūkio bei Švietimo ministerijos, kurios sutiko, kad šaulių dalinių ginklai galètų būti laikomi miškų urẻdijose, girininkijose ir pradžios mokyklų pastatuose $[8,19 ; 9,9 ; 10,10]$. Siekiant sparčiau apmokyti šaulius daryti ant kelių prieššarvines ir kitas kliūtis (susprogdinant, sudeginant, išardant, užverčiant ir pan.), šaulių rinktinès vadui pareikalavus, numatyta skirti reikalingus instruktorius iš kariuomenès dalių. Siekiant tikslų turèjo būti sudaryti detalūs šaulių panaudojimo planai, kuriuos vietos šaulių būrių vadams turejjo padèti parengti komendantūrų šaulių reikalų karininkai. Be to, turèjo būti sudaromi žemėlapiai, kuriuose būtų pažymėti išardytini ar degintini tiltai, sprogdintini objektai, užtvaros, perkasos, linijos, kur numatoma gintis iš anksto išsidèstant, linijos, kur numatoma gintis pasitraukiant, pasitraukimo kryptys bei susitelkimo vietos. Visi šie sumanymai ir pasirengimas vykdyti nurodymus turëjo būti igyvendinti iki $1940 \mathrm{~m}$. liepos 15 dienos. Reikia pažymėti, kad, smarkiai augant šaulių skaičiui, $1940 \mathrm{~m}$. buvo susidariusi kuriozinė situacija. Kariuomenès štabas atkreipé dèmesí, kad divizijose parengti planavimo dokumentai neatitiko esamos situacijos - buvo numatyta panaudoti kone perpus mažiau šaulių, pavyzdžiui, Kauno šaulių rinktinèje 1940 m. gegužès mėn. faktinis šaulių skaičius siekè 4 670, o ị planus įtraukti tik 2489 šauliai, nemobilizuojamų šaulių skaičius siekè 2510 , o ị planus buvo ịtraukti tik 1569 šauliai. Divizijos vẻlavo atnaujinti esamus planus [20,48]. Kaip matome, likus mènesiui iki numatyto termino, priešo kariuomenè iš rytų nelauktai įsiveržè ị Nepriklausomą Lietuvą. Valstybès gyvenimas pasuko neplanuota vaga.

\section{KOVINIŲ GEBE்JIMŲ UGDYMAS ŠAULIŲ PADALINIUOSE}

Lietuvos kariuomenès modernizavimo metu, kuris prasidejo $1935 \mathrm{~m}$. pradžioje, jos vadovybė, kaip jau buvo minèta, palaipsniui èmėsi igyvendinti Šaulių sąjungos integravimą i kariuomenès ir valstybės gynybos sistemą. Atsižvelgiant ị šauliams formuojamas gynybines ir partizaninio karo užduotis, buvo siekiama atitinkamą šaulių kontingentą apmokyti ir parengti konkretiems uždaviniams igyvendinti. Pagrindinis dėmesys buvo sutelktas i netarnavusius ir karo atveju nemobilizuojamus šaulius. Kariuomenès ir LŠS vadovybès parengè ịvairių mokymo programų ịvairios trukmès kursams. $1937 \mathrm{~m}$. kariuomenès vadovybès organizuotuose 7 dienų kariuomenèje netarnavusių šaulių mokymuose dalyvavo 1164 asmenys [32, 415]. Bendras mokymų procesas suintensyvejjo 1938-1940 m., kai šaulius siekta supažindinti su naujausia ginkluote, topografija, sprogdinimų teorija ir praktika bei partizaninio karo taktika $[32,415]$. Reaguodamas ì kariuomenès štabo paskelbtus nurodymus „Šauliams mobilizacijos ir operacijų metu panaudoti“, $1938 \mathrm{~m}$. birželio $28 \mathrm{~d}$. kariuomenès vadas brg. gen. S. Raštikis pritarè kariuomenès štabo ir LŠS vadovybès parengtam šaulių būrių vadų ir padejejeju kursų planui $[3,218]$ bei programai [4, 219-221]. Plano tikslas buvo parengti nemobilizuojamų šaulių kontingentą - būrių vadus 
ir jų padejejus, kuris po mobilizacijos būtų pajègus perimti vadovavimą šaulių būriams. Vieno mėnesio kursus pavesta organizuoti péstininkų divizijų vadovybei jai pavaldžiuose daliniuose. I pėstininkų divizija kursus turèjo organizuoti Panevėžyje nuo liepos 11 iki rugpjūčio 12 d., II pèst. divizija - Kaune nuo rugpjūčio 1 iki rugsẻjo 2 d., III pèst. divizija - Šiauliuose nuo liepos 20 iki rugpjūčio 21 dienos. Kursams kiekviena divizija privalèjo skirti po 2-3 karininkus ir 4 puskarininkius, taip pat aprūpinti klausytojus visa materialine baze, įskaitant ir gyvenimo sąlygas. It kursus numatyta išsiųsti atstovus iš 50 \% šaulių rinktinèse esančių būrių. Iš viso 430 šaulių. Kaune numatyta parengti 160 šaulių, Šiauliuose - 140, Panevèžyje - 130. Kursuose dalyvaujantys šauliai turèjo turèti vadovavimo gebejimų ir mažiausiai vidurinès mokyklos išsilavinimą. Kursams buvo numatytos 189 valandos užsiemimų, iš kurių 44 val. skirtos šaudybai, 42 - sprogdinimams ir ardymams, 39 - kautynèms, po 12 topografijai ir ginklams, 9 - rikiuotei, po 8 - lauko ir vidaus tarnyboms ir 7 - žinių patikrinimui [3, 218]. Šauliai turejo semtis žinių studijuodami įvairius kariuomenès statutus: kautynių - P51 (Péstininku statutas P-51. II dalis. Kautynès. Kaunas, 1936), sprogdinimų ir ardymų - Tch9 ir Tch64 (Keliu tiesimas, taisymas ir ardymas: Tch-64. Kaunas, 1936), šaudymo - G30 (Šautuvų, karabinų, l. kulkosvaidžiu ir pistoletų šaudymo ir rankiniu granatų svaidymo statutas G-30, Kaunas, 1937) ir kt. Mokant kautynių daugiausia dèmesio planuota skirti būrio veiksmams puolant, ginantis, stabdant, žvalgant - 10 val., nakties veiksmams -8 val., būrio veiksmams pasalose ir užpuolimams - 6 val., partizaniniams veiksmams - 2 val. ir kt. [4, 219-221]. Kaip ir buvo numatyta, kursai buvo igyvendinti, ir netrukus sulaukta pėstininkų divizijų vadovybės refleksijų. 1938 m. spalị savo vertinimus išsakė II pėst. divizijos vadas div. gen. Edvardas Adamkavičius ir jo štabas. Jie konstatavo, kad šaudymo igūdžiams vietoje planuotų 44 val. prireikè 56 valandų. Atsiliepime išreikštas pageidavimas ateityje daugiau dėmesio skirti ginkluotei, nes šauliai dažniausia kariuomenejje netarnavę, , „<...> nežino net paprasčiausio $98 \mathrm{~m}$. vokiško šautuvo [šautuvas Mauser, 1898 m. modelis - aut. pastaba]. Kitų ginklų kaip lengv. ir sunk. kulkosvaidžių visai net nematę. Su rankinèm granatom tas pats. O šauliams tas būtina" $[7,225]$. Pažymèta, kad sisteminius puolamuosius ir gynybinius veiksmus šauliai vargiai ar kada naudos, todèl siūlyta daugiau dèmesio sutelkti ị kovinius veiksmus naktị ir pasalų rengimą. Taip pat siūlyta keletą valandų skirti ir ryšių priemonėms - pasiklausymui ir telefono linijų gadinimui. Kartu konstatuotas per mažas kadrinių puskarininkių skaičius, kuris buvo numatytas tokių didelių grupių mokymui. Išreikštas pageidavimas kursus pailginti iki dviejų mėnesių, nes, divizijos vadovybės manymu, per numatytą laiką netarnavusiesiems kariuomenejje ịskiepyti būtinas žinias yra sudètinga [7, 225]. Greta šaulių būrių vadovaujančio personalo rengimo buvo organizuojami ir kiti kursai. Vieni tokių buvo 9 dienų kursai kliūčių ir ardymų instruktoriams paruošti. Šie mokymai taip pat atitiko XX a. 4-ajame dešimtmetyje numatytas užduotis šauliams karo atveju. Kaip savo tyrimuose pažymi Vytautas Jokubauskas, nuo 1939 m. kovo mèn. pabaigos mokytis sprogdinti ịvairius objektus ị inžinerinius kariuomenės dalinius turejjo būti pasiųsta po vieną nemobilizuojamą šaulį iš kiekvieno organizacijos būrio (iš viso 842 žmonès) [32, 417]. Tokių apmokymų poreikis buvo milžiniškas. Pavyzdžiui, 1939 m. rugpjūčio mèn. Vilkaviškio šaulių rinktinėje sprogdinimo užduotims reikèjo parengti net 59 asmenis iš 68, kurie su sprogdinimo darbais nebuvo susipažinę, bet buvo ịtraukti i tokių užduočių vykdymo komandas [16, 100]. $1940 \mathrm{~m}$. pavasarị 1-ame inžinerijos batalione buvo parengti 58 I Kauno rinktinès šauliai instruktoriai. Augant karo grèsmei, kariuomenès vadovybė nurodė mokymo programos valandas, skirtas antriniams dalykams studijuoti, perkelti, stengiantis kuo nuodugniau išeiti tuos dalykus, kurie yra svarbiausi vykdant karo metu šauliams numatomus uždavinius $[14,162]$. 1940 m. kursų trukmė padidinta viena diena ir 
sudare 10 dienų apmokymų ciklą $[17,156]$. Taip pat reikia pažymėti, kad kursai ir mokymo stovyklos netarnavusiesiems kariuomenejje buvo igyvendinami toje pačioje vietoje $[18,52]$. Kursai vyko iki pat paskutinès laisvos valstybės minutès. Prasidejjus Lietuvos okupacijai, jau kitą dieną jie buvo sustabdyti $[22,152]$. Rengiant kliūčių ardymo instruktorius, kautynèms skirta 5 val., šaudybai - 7 val., ginklams -6 val., šaudymams - 3 val., sprogdinimams -44 valandos [11, 169-170].

1940 m. pavasarị priedangą vykdančioms šaulių rinktinėms buvo įsakyta sudaryti sprogdintojų komandas, kurios pavojaus atveju turejo susprogdinti tiltus. Pavyzdžiui, Marijampolès šaulių rinktinès uždavinys: „Susprogdinti gelžbetoninį tiltą per Šešupę, Kalvarijos mieste Vilniaus gatvejje, per 3 val. po įsakymo gavimo, sudaryta komanda iš 2-os Kalvarijos šaulių kuopos: Komandos viršininkas ats. viršila Martinkaitis Albertas, pavaduotojas ats. pusk. Latoža Juozas, Kružikas Jonas, Rutkauskas Klemensas, Šermukšnis Adolfas ir t. t. Bendrai 27 asmenys. Susprogdinti plento tiltą per Šešupę pietinėje Kalvarijos miesto dalyje <...>: Komandos viršininkas ats. viršila Matulevičius Juozas, pavaduotojas ats. pusk. Zareckas Vladas, Mackevičius Jonas, Vaičiula Juozas ir t. t. Bendrai 35 asmenys. Susprogdinti malūno tvenkinị Kalvarijos dvare 2 val. 10 min. po ịsakymo gavimo. Komandos viršininkas ats. pusk. Tupčiauskas Pranas, pavaduotojas ats. jaun. pusk. Žemaitis Vincas, Jokubauskas Jurgis ir t. t. Bendrai 11 asmenų. Susprogdinti geležinkelio tiltą per upę Šešupę, Kazlų-Rūdos Šeštokų ruože $45 \mathrm{klm}$. Prie Kalvarijos. 2 val. po ịsakymo gavimo. Komandos viršininkas ats. viršila Račinskas Jurgis, pavaduotojas ats. psk. Kerza Olesius, Gražulis Pijus ir t. t. Bendrai 13 asmenų“ $[15,109-111]$. Divizijų vadovybè, siekdama, kad numatytų uždavinių igyvendinimas karo atveju vyktų sklandžiai, rūpinosi sprogstamosios medžiagos, skirtos užduotims, išdèstymu kuo arčiau objektų $[5,102]$.

Ivairiuose kursuose ir mokymuose sukaupta šaulių patirtis buvo testuojama ịvairiuose manevruose, kuriuos organizavo kariuomenès vadovybė. 1938-1940 m. manevruose buvo tikrinami šaulių gebejjimai vykdyti partizaninius kovos veiksmus ir stabdomąsias kautynes. Ivertinus anksčiau paminėtus vykdomus mokymus, išskirtinas jų kompleksiškumas ir aiškus suderinimas su rengiamais valstybès gynybos planais.

1940 m. birželio 15 d. Lietuvos Respublikos vyriausybei prièmus sovietų ultimatumą, prasidèjo valstybės okupacija. İsakymo priešintis Lietuvos kariuomenè, o kartu ir šauliai nesulaukè, prasidejo sovietizacijos procesai, o netrukus okupantų taikinyje atsidūrè ir Lietuvos šaulių sąunga [40, 1-47], apie kurios uždavinius karo metu priešas buvo informuotas. Specialiame 1940 m. išleistame leidinyje apie Lietuvą, aptariant Šaulių sąjungą, buvo pažymima, kad karo atveju šauliams pafrontės zonoje priskiriama žvalgybos bei partizaninių veiksmų funkcija [25, 39-40]. 1940 m. liepos mèn. Lietuvos šaulių sąunga buvo likviduota, vadai suimti, o ginklai atiteko sovietų represinėms struktūroms, tačiau, kaip pažymi istorikas Sigitas Jegelevičius, nors represinès struktūros sugebejo suardyti ir likviduoti organizacijos vadovaujantị personalą, tačiau per keliolika taikos metų suformuota struktūra, kurios pagrindas buvo būriai, veikę teritoriniu principu, liko nesuardyta. Šauliai ị kovą pakilo $1941 \mathrm{~m}$. vasarą, Birželio sukilimo metu, ir, kaip teigia kai kurie autoriai, buvo pagrindine šio sukilimo jèga [28, 80]. Čia izžvelgsime ne tik nesuardytą šaulių organizacijos struktūrinį tinklą, socialinius ryšius ir jo veikimą, bet ir pasirengimą stoti ị kovą ir veikti savarankiškai naujomis nenumatytomis aplinkybemis. $\mathrm{XX}$ a. 4-ojo dešimtmečio antrojoje puseje Lietuvoje vykdytas šaulių parengimas ịvairioms karinėms užduotims davė rezultatų. Šauliai pasklido po įvairias militarines arba sukarintas formuotes vokiečių okupacijos metais (šaulių vaidmenị jose plačiai yra aptaręs istorikas Hektoras Vitkus), buvę šauliai buvo susiję su Lietuvos laisvės armijos pogrindine veikla ir 
aktyviai dalyvavo 1944 m. prasidejusiame partizaniniame kare. Tad tikètina, kad per kelerius metus sukaupta patirtis ir igyti gebejjimai tarpukario Lietuvoje buvo efektyviai realizuoti Lietuvos rezistencinèje kovoje, kuri po karo truko dar beveik ištisą dešimtmetị.

\section{IŠVADOS}

Apibendrinant Lietuvos šaulių sąjungos narių parengties karinėms užduotims vykdyti XX a. 4-ajame dešimtmetyje atliktą tyrimą, galima daryti išvadą, jog ịgyvendindama Lietuvos šaulių sąjungos integravimą í valstybès gynybos sistemą, kariuomenès vadovybė XX a. 4-ojo dešimtmečio antrojoje pusejje rengè planus, kuriuose aiškiai apibrèžè šaulių vietą gynybos sistemoje, suformulavo konkrečias užduotis: užtikrinti kariuomenès mobilizacijos priedangą, karo atveju - priešininko pajègų stabdymą, įrengiant kliūtis bei naikinant inžinerinius objektus, vykdyti žvalgybos veiksmus, o atsidūrus priešo užnugaryje, pradèti partizaninius veiksmus. Besikeičiant geopolitinei Lietuvos valstybès situacijai, šie planai buvo operatyviai koreguojami ir tikslinami. Planų sudarymas, administravimas ir realizavimas buvo patikètas kariuomenès divizijų ir šaulių sąjungos vadovybèms, kurios, nepaisant iškylančių materialinių problemų ir organizacinių nesklandumų, numatytus uždavinius sẻkmingai realizuodavo.

Gynybinių ir kovinių uždavinių partizaninio karo sąlygomis igyvendinimui reikejjo parengti nemobilizuojamų šaulių kontingentą, kurio ženklią dalị sudarè ūkininkai, tarnautojai, mokytojai, atstovaujantys patriotiškai nusiteikusiems Lietuvos periferijos gyventojams. Galima daryti išvadą, kad būtent šie Lietuvos šaulių sąjungai priklausę žmonès buvo vietos bendruomenes jungiantys asmenys, kurie, iškilus politinei krizei, apie save turèjo sutelkti patikimus, socialiniais ryšiais susietus artimos aplinkos žmones. Šiems asmenims ir buvo stengiamasi įdiegti vadovavimo būriams gebejimus, suteikti specialių taktinių igūdžių, būtinų kovojant partizaninị karą. Šaulių rengimas vyko lygiagrečiai su kariuomenės vadovybės planavimo veiksmais, nuolat tobulinant ir papildant karinių mokymų turinį.

Šaulių parengtis karinėms užduotims vykdyti XX a. 4-uoju dešimtmečiu Lietuvoje apèmè be išimties visus sąjungos padalinius, kurie mokymams skirdavo nustatytą skaičių žmonių. Per dvejus su puse - trejus intensyvių mokymų ir pratybų Lietuvoje metus (1937/1938-1940 m.) ivvairių specialių gebejimų - vadovavimo, kliūčių ịrengimo, sprogdinimų, ardymų, kautynių bei partizaninio karo veiksmų - pirminiais skaičiavimais, igijo nuo 15 iki 20 \% Šaulių sąjungos narių. Tai leidžia patvirtinti istoriografijoje suformuotą teigini, kad mokymų metu sukaupta karinè patirtis galejjo būti sèkmingai panaudota Lietuvos teritorijoje partizaninio karo metu Antrojo pasaulinio karo pabaigoje ir jam pasibaigus.

Gauta 20150907

Priimta 20151111

\section{Šaltiniai ir literatūra}

[1] 19370429 LŠS II Ukmergès rinktinès veikimo planai pavojaus metu, slaptas asmeniškas. Lietuvos centrinis valstybès archyvas, f. 509, ap. 1, b. 382, 1. 1-17.

[2] 19380521 LR KAM Kariuomenès štabas, I skyrius, Nr. 798 slaptas-asmeniškas, Šauliams mobilizacijos ir operacijų metu panaudoti nurodymai. LCVA, f. 929, ap. 3, b. 1024, 1. 4-7.

[3] 19380625 Šaulių būrių vadų ir padejejų kursų planas. LCVA, f. 510, ap. 1, b. 342, 1. 218.

[4] 19380625 Šaulių būrių vadų ir padejejjų kursų programa. LCVA, f. 510, ap. 1, b. 342, 1. 219-221.

[5] 19380825 LR KAM II pèst. diviz. štabas, I skyrius, Nr. 3449 slaptas, Vilkaviškio apskrities komendantui. LCVA, f. 510, ap. 1, b. 342, 1. 102.

[6] 19380919 LR KAM II pèst. diviz. štabas, I skyrius, Nr. 4509 slaptas-asmeniškas, Šauliams mo- 
bilizacijos ir operacijų metu panaudoti nurodymai. LCVA, f. 929, ap. 3, b. 1024, 1. 35-38.

[7] 19381019 Pastabos apie mokymą šaulių būrių vadams ir jų padejjejjams tobulinti kursuose, slaptas. LCVA, f. 510, ap. 1, b. 342, 1. 225.

[8] 19390221 LR KAM I skyrius, Nr. 37259, slaptas-asmeniškas ponui Vidaus reikalų ministrui. LCVA, f. 929, ap. 3, b. 1024, 1. 19.

[9] 19390221 LR KAM I skyrius, Nr. 37260, slaptas-asmeniškas ponui Žemès ùkio ministrui. LCVA, f. 929, ap. 3, b. 1024, 1. 9.

[10] 19390221 LR KAM I skyrius, Nr. 37258, slaptas-asmeniškas ponui švietimo ministrui. LCVA, f. 929 , ap. 3, b. 1024, 1. 10.

[11] 193905 Šaulių sąjungos kliūčių ardymo instruktorių kursų programa. LCVA, f. 510, ap. 1, b. 342, 1. $169-170$.

[12] 19390516 LR KAM XVIII Biržų šaulių rinktinès vadas, Nr. 47, slaptas, Šaulių sajungos vadui raportas. $L C V A$, f. 561, ap. 2, b. 1312, 1. 67.

[13] 19390516 LR KAM VII Šiaulių šaulių rinktinès vadas, Nr. 195 sl., slaptai, Šaulių sąjungos vadui raportas. $L C V A$, f. 561, ap. 2, b. 1312, 1. 64 .

[14] 19390612 LR KAM Kariuomenès štabas I skyrius, Nr. 37918 slaptas [Kariuomenès štabo viršininko pranešimas divizijų vadams, karo technikos ir kavalerijos viršininkams, šaulių sajungos vadui]. LCVA, f. 510, ap. 1, b. 342, 1. 162.

[15] 193907 XIV Marijampolès šaulių sprogdinimams bei ardymams atlikti komandų sąrašas. LCVA, f. 510, ap. 1, b. 342, 1. 109-112.

[16] 19390805 LR KAM Vilkaviškio komendantūra, Mobilizacijos skyrius, Nr. 495 slaptai, II pèst. divizijos vadui raportas, LCVA, f. 510, ap. 1, b. 342, 1. 100.

[17] 19400409 LR KAM Šaulių sajungos vadas, Nr. 6172, Rinktinių vadams. LCVA, f. 561, ap. 2, b. $1312,1.156$.

[18] 19400413 LR KAM 9-o pèst. liet. kunig. Vytenio Pulko vadas, Nr. 316, slaptas II pèstininkų divizijos vadui raportas. LCVA, f. 510, ap. 1, b. 342, 1. 52.

[19] 19400429 LR KAM II pèst. div. štabas, Nr. 2233, slaptas asmeniškas, Nurodymai PABn panaudoti. LCVA, f. 929, ap. 3, b. 1153, 1. 7-8.

[20] 19400516 LR KAM Kariuomenès štabas, I skyrius, Nr. 603, slaptas asmeniškas II PD vadui. LCVA, f. 510, ap. 1, b. 342, 1. 48.

[21] 19400601 LR KAM Telšiu šaulių rinktinès vadas, Nr. 1173, Šaulių sajungos vadui raportas. LCVA, f. 561, ap. 2, b. 1312, 1. 142.

[22] 19400618 LR KAM III Vilkaviškio šaulių rinktinès vadas, Nr. 1607, Šaulių sajungos vadui raportas. $L C V A$, f. 561, ap. 2, b. 1312, 1. 152.

[23] ABROMAVIČIUS, Stanislovas; ŽYGELIS, Dalius. Didžiosios Kovos apygardos vadas Mečislovas Kestenis - Serbentas. Karys, 2015, Nr. 3, p. 46-51.

[24] BUTAR, Prit. Tarp milžinų. Mūšis dèl Baltijos šaliu 1939-1945. Kaunas: Vox altera, 2014. 336 p.

[25] БУБНОВ, М. А. Литва. Москва: Государственное военное издательство Наркомата обороны Союза ССР, 1940, с. 39-40.

[26] ČERNIAUSKAS, Norbertas. Nepriklausomos Lietuvos studentija Lietuvos šaulių sąungos veikloje 1919-1940. Iš: Lietuvos šauliu sajunga: praeitis, dabartis, ateitis. Kaunas, 2009, p. 25-38.

[27] JANAUSKAS, Pranas. Šaulių vaidmuo likviduojant lenkų karinès organizacijos (POW) maištą Lietuvoje 1919 metais. Ǐs: Lietuvos šauliu sajungos istorijos fragmentai. Kaunas, 2002, p. 54-61.

[28] JEGELEVIČIUS, Sigitas. Birželio sukilimo brendimas ir jo prasmė, $1941 \mathrm{~m}$. birželio sukilimas - Tautos valios vykdymas. Iš: Atmintis. Kaunas, 2002, p. 80.

[29] JEGELEVIČIUS, Sigitas. Nemunaičio šaulių būrys ir jo vieta LŠS XIX a. (Alytaus) rinktinès 
istorijoje. Iš: Lietuvos šauliu sajungos istorijos fragmentai. Kaunas, 2002, p. 28-53.

[30] JEGELEVIČIUS, Sigitas. Šauliai 1940-1941 m. antisovietinëje kovoje. Ǐs: Lietuvos šauliu sajunga valstybés ir visuomenés tarnyboje 1919-2004. Kaunas, 2005, p. 157-180.

[31] JOKUBAUSKAS, Vytautas. „Vienui vieni“: šaulių rengimas partizaniniam karui 1924-1940 m. Lietuvoje. Istorija, 2012, t. LXXXVI, p. 11-24.

[32] JOKUBAUSKAS, Vytautas. „Mažuju kariuomeniu“ galia ir paramilitarizmas. Tarpukario Lietuvos atvejis. Klaipeda: Klaipėdos universiteto leidykla, 2014. 587 p.

[33] JUREVIČIŪTĖ, Aušra; VEILENTIENĖ, Audronė. Lietuvos šauliai Nepriklausomybès kovose (19191920). Iš: Lietuvos šauliu sajunga valstybès ir visuomenés tarnyboje 1919-2004. Kaunas, 2005, p. 23-55.

[34] KUODYTĖ, Dalia. Šauliai antinaciniame pasipriešinime ir partizaniniame kare (1941-1953). Iš: Lietuvos šauliu sajunga valstybes ir visuomenés tarnyboje 1919-2004. Kaunas, 2005, p. 181-197.

[35] MARKUCKYTĖ, Elena; PILKAUSKAS, Donatas. Kovoję už brangią Tèvynę: Algimanto apygardos partizanu istorija. Panevežys, 2008.

[36] MARKUCKYTĖ, Elena; PILKAUSKAS, Donatas. Kovoję už brangia Tèvynę: Vyčio apygardos partizanu istorija. Panevė̌ys, 2012.

[37] MUTURAS, Algimantas. Mažeikiu šauliu tryliktoji. Mažeikiai, 2008. 200 p.

[38] NEFAS, Mindaugas. Lietuvos šaulių sąjungos ideologija: vidiniai ir išoriniai jos kūrejjai. Iš: Lietuvos šauliu sajunga: praeitis, dabartis, ateitis. Kaunas, 2009, p. 11-24.

[39] NOREIKA, Dainius. Nuo Lietuvos šaulių iki miško brolių: lokalios ginkluotos struktūros raidos tyrimas. Genocidas ir rezistencija, 2012, Nr. 2 (32), p. 47-73

[40] RAŠTIKIS, Stasys. Lietuvos šauliu sajungos likvidavimas, Lietuviu archyvas, Bolševizmo metai. Studijų biuro leidinys. Vilnius, 1944, p. 1-47.

[41] STATKUS, Vytenis. Lietuvos ginkluotos pajegos 1918-1940 m. Chicago, 1986. 1040 p.

[42] STRAZDAS, Kazys. Ukmergés krašto laisvés kovų keliais. Kaunas, 2012.

[43] VAIČENONIS, Jonas. Lietuvos Šaulių sajunga Valstybès gynyboje 1935-1940 metais. Iš: Lietuvos šauliu sajungos istorijos fragmentai. Kaunas, 2002, p. 110-119.

[44] VAIČENONIS, Jonas. Lietuvos šaulių sajungos integracijos ị valstybės gynybos sistemą XX a. 3-4-uoju dešimtmečiais proceso bruožai. Acta Historica Universitatis Klaipedensis. T. XXVIII: Paramilitarism in the Eastern Baltics, 1918-1940: Case Studies and Comparisons / Paramilitarizmas Rytu Baltijos regione 1918-1940: atvejo studijos ir lyginimai. Klaipeda, 2014, p. 128-139.

[45] VAREIKIS, Vygantas. Bandymas apčiuopti šaknis: ideologinès Lietuvos šaulių sajungos ištakos. Acta Historica Universitatis Klaipedensis. T. XXVIII: Paramilitarism in the Eastern Baltics, 1918-1940: Case Studies and Comparison / Paramilitarizmas Rytu Baltijos regione 1918-1940: atvejo studijos ir lyginimai. Klaipeda, 2014, p. 19-40.

[46] VAREIKIS, Vygantas. Dèl „lango ị platųji pasaulį“: Lietuvos šaulių sąjunga 1923 metų Klaipedos sukilimo metu. Ǐs: Lietuvos šauliu sajunga: praeitis, dabartis, ateitis. Kaunas, 2009, p. 57-76.

[47] VAREIKIS, Vygantas. Šaulių sąunga, lenkai, žydai: LŠS ideologijos ir propagandos bruožai. Iš: Lietuvos šauliu sajungos istorijos fragmentai. Kaunas, 2002, p. 126-142.

[48] ŽYGELIS, Dalius. Algimanto partizanų apygarda. Karys, 2014, Nr. 11, p. 44-53.

[49] ŽYGELIS, Dalius. Antanas Ylius - Vilkas. Dvasininko ir kovotojo kelias. Karys, 2014, Nr. 4, p. 48-53.

[50] ŽYGELIS, Dalius. Vaclovas Voveris - Žaibas. „Karo po karo“ didvyris. Karys, 2014, Nr. 3, p. 46-53.

[51] ŽYGELIS, Dalius; RAPALIS, Aurimas. Platelių krašto partizanas Kostas Gelžinis - Girenas. Karys, 2014, Nr. 6, p. 46-53.

[52] ŽILYTĖ, Enrika. Lietuvos partizanų vadovybès kolektyvinè biografija. VU Istorijos fakultetas, istorijos bakalauro darbas. Vilnius, 2014. 
JONAS VAIČENONIS

\section{The Lithuanian Riflemen's Union in state defense in the third decade of the 20th century: Riflemen preparation for military actions}

Summary

The article discusses a purposeful formation of military and organizational skills in the Lithuanian Riflemen's Union in the third decade of the 20th century in Lithuania. This particular period was significant for the processes of intensive army modernization and reformation and the integration of the Lithuanian Riflemen's Union into the state defense system. The article analyses the development of riflemen preparation for the military actions. It is claimed that the experience gained in military training could be, had to be and was used during the Lithuanian guerilla war in 1944. In the second half of the third decade of the 20th century, in order to integrate the Lithuanian Riflemen's Union into the state defense system, the leaders of the Lithuanian army prepared plans which clearly defined the place of the riflemen in state defense. Specific tasks were formed according to which the riflemen had to guarantee the undercover of mobilization; to resist the enemy in case of war by constructing barriers or destroying objects of engineering; to work as scouts; to initiate partisan activity in the rear of the enemy. The creation, administration and realization of the plans were trusted for the headquarters of army divisions and the Riflemen's Union, which successfully implemented the tasks despite certain problems. In case of the critical circumstances, the members of the Lithuanian Riflemen's Union had to be able to gather and unite reliable people from the local communities to fight for the Lithuanian freedom. Therefore, riflemen training had to help them to acquire leading skills and knowledge of partisan war. The preparation of riflemen was in accord with the plans of the army leadership; the content of riflemen training was often revised and updated. In the third decade of the 20th century, the preparation of riflemen for military actions involved all units of the Lithuanian Riflemen's Union. During the two or three years of intensive training in Lithuania (1937/1938-1940), approximately $15-20 \%$ of riflemen acquired various special skills: group leadership, barrier building, organizing explosions; conducting works of deconstruction; fighting and organizing partisan war. Thus it can be stated that the fighting experience gained during the training could have been successfully used during the partisan war at the end of and after the WWII.

Key words: Lithuanian Riflemen's Union, organizing partisan war, Lithuanian army, state defense, guerilla war 